ices to faculty and students." Three months, 1970.

Andrew J. Eaton, Director of Libraries, Washington University, St. Louis. "For study of three aspects of university library administration: modern management techniques and their applicability, financial support for private institutions, and interlibrary cooperation in metropolitan areas." Three months, 1969.

James Govan, Librarian, Swarthmore College. "For examination of innovative programs in university libraries in the areas of automation, audio-visual materials, and staff subject specialists, for possible application of these in a large college library." Three months, 1970.

Tyrus G. Harmsen, College Librarian, Occidental College. "To study the future of liberal arts college libraries through visits to selected institutions and through independent study." Three months, 1969.

Miles M. Jackson, Jr., Director of Libraries, Atlanta University, Atlanta, Ga. (on leave at present as a Fulbright lecturer in Teheran, Iran). "For study and review of recent developments in library administration and services in institutions of higher education within the United States." Three months, 1970.

Irving Lieberman, Director, School of Librarianship, University of Washington. "To study the changes in library and information science education as evidenced in some of the existing programs in the United States and Canada, with particular emphasis on curriculum, advanced degree work, and physical facilities." Three months, 1969.

Ellsworth G. Mason, Director of Library Services, Hofstra University. "For an investigation into significant successes in handling the major problems that result from rapid expansion in research libraries." Seven months, 1969-70.

Miss Luella R. Pollock, Librarian, Reed College. "To study computer methods and programming as applied to a medium to small library system." Six months, 1970.

Eldred Smith, Head, Search Division, Acquisitions Department, General Library, University of California at Berkeley. "To investigate the current and potential use of specialist librarians-their qualifications, the services they provide, how they fit into and affect the library organization-in a selected group of major academic research libraries." Fall 1969-Spring 1970.

Mrs. Jessie Carney Smith, University Librarian, Fisk University. "For a survey of Negro college libraries, with particular emphasis on the special Negro collections that are in some of these libraries." Twelve months, 1969-70.
David Weber, Associate Director of Libraries, Stanford University. "For an investigation of university trends and prospects for their libraries, conducted through discussions with faculty, administrators, and librarians, and by a program of reading on higher education." Three to four months, 1970.

Robert Wedgeworth, Assistant Chief Order Librarian, Brown University. "To attempt to identify and analyze the operations of American and West European booksellers who offer, or plan to offer, foreign publications on a blanket order as this may be applied to libraries of various sizes and types; the investigation to involve visits to foreign booksellers." Three and one-half months, 1969.

\section{PITT LIBRARY SCHOOL REORGANIZED; TWO ACADEMIC DEPARTMENTS CREATED}

The University of Pittsburgh's graduate school of library and information sciences has been reorganized and two academic departments have been created within the existing administrative framework of the school. A department of information and communication science, culmination of the school's increasing commitment since 1963 to the teaching of information/communication science courses as a vital area of professional study in modern librarianship, has been established with Professor Allen Kent as Chairman. A department of library science, with Dr. Frank B. Sessa as Chairman, has been formed and assigned responsibility for research and instruction in the fundamental concepts and more traditional applications of librarianship. Previously, the school has functioned as a single unit, without departmentalization of internal functions.

"The size and complexity of the graduate school of library and information sciences has grown to such an extent," explained Dr. Harold Lancour, Dean of the graduate school, "that it became clear an administrative division was essential to achieve the needed simplification of our operations. The departmental organization is a recognized academic arrangement giving suitable status to those responsible for developing academic programs and desirable visibility to major activities of the school." The division does not imply that two different degrees will be awarded. Regardless of the field of specialization the student chooses while in the master's program, the Master of Library Science degree will be awarded upon completion, as before. 